\title{
Influence of Tween 80 on the Mycolic Acid Composition of Three Cutaneous Corynebacteria
}

\author{
By JACQUELINE CHEVALIER, ${ }^{1}$ * MARIE-THÉRÈSE POMMIER, ${ }^{2}$ \\ ANDRÉE CREMIEUX ${ }^{1}$ AND GEORGES MICHEL ${ }^{2}$ \\ ${ }^{1}$ Laboratoire de Microbiologie, Hygiène Microbienne, Immunologie, Faculté de Pharmacie, \\ 27 Boulevard Jean Moulin, 13385 Marseille Cédex 5, France \\ ${ }^{2}$ Laboratoire de Biochimie Microbienne, Université Claude Bernard, Lyon I, 43 Boulevard du 11 \\ Novembre 1918, 69622 Villeurbanne Cédex, France
}

(Received 4 January 1988; revised 9 April 1988)

Changes in the mycolic acid composition of three cutaneous strains of corynebacteria were caused by the addition of Tween 80 to the culture medium. Gas chromatography-mass spectrometry showed that the carbon chain length and the degree of unsaturation had been affected: the levels of corynomycolic acid with 36 carbon atoms and two double bonds increased significantly.

\section{INTRODUCTION}

Mycolic acids (2-alkyl 3-hydroxy fatty acids) are commonly found in the lipids of Corynebacterium, Rhodococcus, Nocardia and Mycobacterium (Collins et al., 1982; Goodfellow et al., 1976; Minnikin et al., 1975, 1978; Yano et al., 1978). Gas chromatography-mass spectrometry analyses of these fatty acids have proved of use in the identification of medically important coryneform bacteria (Athalye et al., 1984).

Recently, several workers have reported that the mycolic acid composition of corynebacteria, nocardia and mycobacteria was modified by changes in environmental conditions such as growth temperature (Suzuki et al., 1969; Toriyama et al., 1980; Tomiyasu et al., 1981) and substrates (Cooper et al., 1979). Tween 80 is often added to enhance the growth rate of some cutaneous corynebacteria in commonly used media (McGinley et al., 1985a, b; Riley et al., 1979). In this study, we compared the effect of Tween 80 on the mycolic acid composition of three cutaneous strains of corynebacteria, two of which belong to the pathogenic JK group corynebacteria.

\section{METHODS}

Strains and culture conditions. CIP JK group no. 82451 Corynebacterium sp. was obtained from the Institut Pasteur Collection, Paris, France; CDC JK group wound Corynebacterium sp. and Corynebacterium striatum were kindly supplied by the Center for Disease Control, Atlanta, Georgia, USA, and by the Department of Microbiology, Faculty of Medicine, Strasbourg, France, respectively.

Corynebacteria were grown in shaken flasks of Tryptic Soy Broth (Difco) in the presence or absence of Tween $80(0.3 \%$, w/v; Sigma $)$. Cells were harvested by centrifugation, washed with distilled water and freeze-dried.

Cell methanolysis and thin-layer chromatography $(T L C)$. Dried bacteria (about $50 \mathrm{mg}$ ) were degraded by methanolysis (Minnikin et al., 1980), and the hexane extracts were examined for hydroxylated fatty acid methyl esters by TLC on silica gel (Merck) with hexane/diethyl ether $(4: 1, \mathrm{v} / \mathrm{v})$. Spots were located by spraying with a bromothymol blue/sodium hydroxide reagent (Michalec et al., 1975). Preparative chromatography was done under the same conditions, fatty acid methyl esters being located by spraying with a $0.01 \%$ solution of Rhodamine B in ethanol. Spots were scraped off, dissolved in hexane and purified on a silicic acid column (Bio Sil HA 325 mesh, BioRad) eluted with diethyl ether.

Abbreviation: TMS, trimethylsilyl. 
Table 1. Content of mycolic acids $(\%$ of total $)$ of strains grown in the presence or absence of Tween 80

I, cells grown in the absence of Tween 80; II, cells grown in the presence of Tween 80 ; tr, trace amounts. Figures are the means of 3 determinations.

\begin{tabular}{|c|c|c|c|c|c|c|}
\hline \multirow{2}{*}{$\begin{array}{l}\text { No. of } \\
\text { carbon } \\
\text { atoms }\end{array}$} & \multicolumn{2}{|c|}{ 'C. $J K^{\prime}$ CIP } & \multicolumn{2}{|c|}{$' C . J K ' \mathrm{CDC}$} & \multicolumn{2}{|c|}{ C. striatum } \\
\hline & I & II & I & II & I & II \\
\hline $\mathrm{C}_{26}$ & $\operatorname{tr}$ & & & & & 1.6 \\
\hline $\mathrm{C}_{28}$ & $\operatorname{tr}$ & & & $4 \cdot 7$ & $9 \cdot 0$ & $3 \cdot 5$ \\
\hline $\mathrm{C}_{30}$ & $29 \cdot 5$ & $10 \cdot 0$ & $17 \cdot 0$ & $13 \cdot 7$ & $26 \cdot 0$ & $11 \cdot 3$ \\
\hline $\mathrm{C}_{32}$ & $33 \cdot 7$ & $35 \cdot 8$ & $41 \cdot 0$ & $43 \cdot 0$ & $57 \cdot 0$ & $21 \cdot 1$ \\
\hline $\mathrm{C}_{34}$ & 33.8 & $20 \cdot 8$ & $41 \cdot 0$ & $18 \cdot 1$ & $8 \cdot 0$ & $29 \cdot 6$ \\
\hline $\mathrm{C}_{36}$ & $\mathrm{tr}$ & $33 \cdot 4$ & $\operatorname{tr}$ & $20 \cdot 5$ & & 32.9 \\
\hline
\end{tabular}

Gas chromatography $(G C)$ and pyrolysis gas chromatography $(P y-G C)$. Silylation of hydroxylated methyl esters was done according to the method of Tomiyasu et al. (1981). The methyl mycolate trimethylsilyl (TMS) ethers were separated on an Intersmat chromatograph equipped with a flame ionization detector on a column $(0.6 \times 150 \mathrm{~cm})$ packed with $3 \%$ OV 17 on Chromosorb WAW/DMCS (80-100 mesh). The column was maintained at $290^{\circ} \mathrm{C}$ with a nitrogen flow rate of $30 \mathrm{ml} \mathrm{min}^{-1}$. The TMS ether peaks were identified by comparing their retention times to those of standards.

Py-GC (Etemadi, 1967) of mycolic acid methyl esters was done on the same apparatus fitted with a column $(0.3 \times 150 \mathrm{~cm})$ packed with $10 \%$ SE 30 on Chromosorb PAW $(80-100 \mathrm{mesh})$. The column was maintained at $180^{\circ} \mathrm{C}$. The injector temperature was $300^{\circ} \mathrm{C}$.

Gas chromatography-mass spectrometry (GC-MS) analysis. MS of TMS ethers was done on a ZAB HF spectrometer. The molecular separator and the ion source were kept at $260^{\circ} \mathrm{C}$ and the ionization energy was $70 \mathrm{eV}$. The samples were introduced into a Perkin Elmer Sigma 3B gas chromatograph which was operated with a DB 5 column, and the temperature was increased from 260 to $320^{\circ} \mathrm{C}\left(4{ }^{\circ} \mathrm{C} \mathrm{min}-1\right)$; the effluent was analysed by MS.

\section{RESULTS}

TLC analysis of the acid methanolysates of the three strains grown with Tween 80 showed the presence of hydroxylated fatty acid methyl esters. They had the same mobility $\left(R_{F}=0 \cdot 40\right)$ as corynomycolic methyl esters isolated from corynebacteria (Minnikin \& Goodfellow, 1976; Minnikin et al., 1980). The saprophytic cutaneous strain, $C$. striatum, showed approximately the same amount of material when it was grown without Tween 80, whereas the two JK group strains showed only minute traces of mycolic acid methyl esters in the absence of Tween 80 .

The methyl corynomycolates were quantified by GC analysis of the TMS ether derivates (Table 1). Mycolic acids were in the range from $\mathrm{C}_{26}$ to $\mathrm{C}_{36} . \mathrm{C}_{26}$ and $\mathrm{C}_{28}$ compounds never accounted for more than $10.0 \%(\mathrm{w} / \mathrm{w})$ of the total mycolic acid content. The quantity of mycolic acids with 36 carbon atoms increased significantly in cells grown in the presence of Tween 80 (mean percentage from 20.5 to 33.4), while the concentration of $\mathrm{C}_{30}$ mycolic acids decreased.

Py-GC of methyl corynomycolates showed methyl esters of $\mathrm{C}_{12}, \mathrm{C}_{14}$ and $\mathrm{C}_{16}$ fatty acids and $\mathrm{C}_{14}, \mathrm{C}_{16}$ and $\mathrm{C}_{18}$ aldehydes in strains grown without Tween 80. For strains grown in the presence of Tween 80, methyl esters of $C_{14: 0}, C_{14: 1}, C_{16: 0}, C_{16: 1}$ and $C_{18: 1}$ fatty acids and $C_{14}$, $\mathrm{C}_{16: 1}$ and $\mathrm{C}_{18: 0}$ aldehydes were observed.

As reported previously (Yano et al., 1978; Corina \& Sesardic, 1980; Gailiy et al., 1982; Pommier \& Michel, 1985), electron-impact MS gives mass fragment ions which are useful for the determination of straight-chain and branched-chain alkyl units of TMS methyl corynomycolates (Fig. 1).

The molecular ions $[\mathrm{M}]^{+}$were weak in the spectra of derivatives but $[\mathrm{M}-15]^{+}$ions (due to the loss of $\mathrm{CH}_{3}$ ) and $[\mathrm{M}-90]^{+}$ions (due to the loss of $\left(\mathrm{CH}_{3}\right)_{3} \mathrm{SiOH}$ ) were present. The $\mathrm{C}_{2}-\mathrm{C}_{3}$ fragmentations (Fig. 1, ion a) were useful for the determination of the straight-chain alkyl moiety. Furthermore the $\mathrm{C}_{3}-\mathrm{C}_{4}$ fragmentations (Fig. 1, ion b) determined the $\alpha$-branched-chain structure of corynomycolates. 


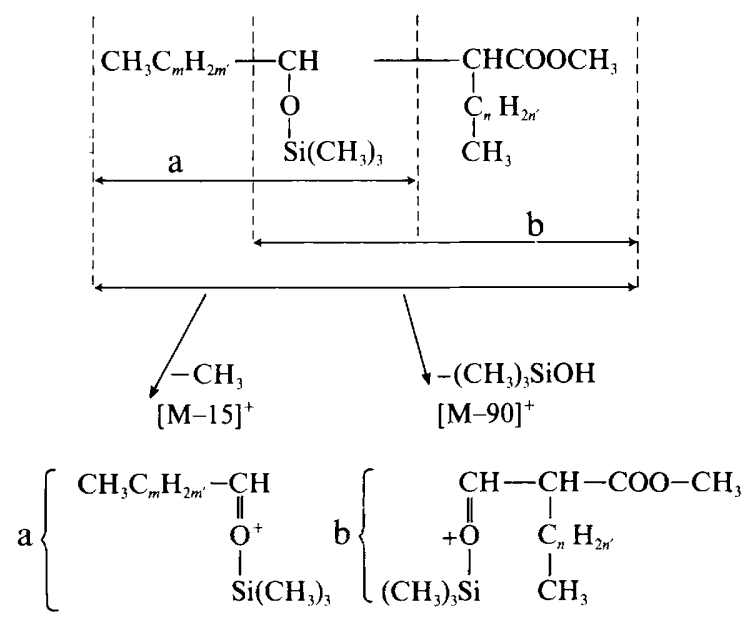

Fig. 1. Fragmentation scheme of TMS-methyl mycolate for electron-impact MS.

Table 2. Mycolic acid composition of the three strains grown in the presence or absence of Tween 80

I, cells grown in the absence of Tween 80; II, cells grown in the presence of Tween 80 .

\begin{tabular}{|c|c|c|c|c|c|c|c|c|c|}
\hline \multirow[b]{2}{*}{ Strain } & & \multicolumn{5}{|c|}{ Fragment ions $(m / z)$} & \multirow{2}{*}{$\begin{array}{c}\text { Formula of } \\
\text { acids }\end{array}$} & \multirow{2}{*}{$\begin{array}{l}\text { Side } \\
\text { chain }\end{array}$} & \multirow{2}{*}{$\begin{array}{l}\text { No. of } \\
\text { double } \\
\text { bonds }\end{array}$} \\
\hline & & a & b & {$[\mathrm{M}-90]^{+}$} & {$[\mathbf{M}-15]^{+}$} & {$[\mathrm{M}]^{+}$} & & & \\
\hline \multirow[t]{2}{*}{${ }^{`} C . J K^{\prime} \mathrm{CIP}$} & I & $\begin{array}{l}285 \\
311 \\
313 \\
341\end{array}$ & $\begin{array}{l}343 \\
371 \\
399\end{array}$ & $\begin{array}{l}462 \\
464 \\
492 \\
520\end{array}$ & $\begin{array}{l}537 \\
539 \\
567 \\
595\end{array}$ & $\begin{array}{l}552 \\
554 \\
582 \\
610\end{array}$ & $\begin{array}{l}\mathrm{C}_{30} \mathrm{H}_{58} \mathrm{O}_{3} \\
\mathrm{C}_{30} \mathrm{H}_{60} \mathrm{O}_{3} \\
\mathrm{C}_{32} \mathrm{H}_{64} \mathrm{O}_{3} \\
\mathrm{C}_{34} \mathrm{H}_{68} \mathrm{O}_{3}\end{array}$ & $\begin{array}{l}\mathrm{C}_{14} \mathrm{H}_{29} \\
\mathrm{C}_{16} \mathrm{H}_{33} \\
\mathrm{C}_{18} \mathrm{H}_{37}\end{array}$ & $\begin{array}{l}1 \\
0 \\
0 \\
0\end{array}$ \\
\hline & II & $\begin{array}{l}311 \\
339\end{array}$ & $\begin{array}{l}341 \\
369 \\
397\end{array}$ & $\begin{array}{l}460 \\
488 \\
516 \\
544\end{array}$ & $\begin{array}{l}535 \\
563 \\
591 \\
619\end{array}$ & $\begin{array}{l}550 \\
578 \\
606 \\
634\end{array}$ & $\begin{array}{l}\mathrm{C}_{30} \mathrm{H}_{56} \mathrm{O}_{3} \\
\mathrm{C}_{32} \mathrm{H}_{60} \mathrm{O}_{3} \\
\mathrm{C}_{34} \mathrm{H}_{64} \mathrm{O}_{3} \\
\mathrm{C}_{36} \mathrm{H}_{68} \mathrm{O}_{3}\end{array}$ & $\begin{array}{l}\mathrm{C}_{14} \mathrm{H}_{27} \\
\mathrm{C}_{16} \mathrm{H}_{31} \\
\mathrm{C}_{18} \mathrm{H}_{35}\end{array}$ & $\begin{array}{l}2 \\
2 \\
2 \\
2\end{array}$ \\
\hline \multirow[t]{2}{*}{${ }^{'} C . J K^{\prime} \mathrm{CDC}$} & I & $\begin{array}{l}285 \\
313\end{array}$ & $\begin{array}{l}343 \\
371\end{array}$ & $\begin{array}{l}464 \\
492\end{array}$ & $\begin{array}{l}539 \\
567\end{array}$ & $\begin{array}{l}554 \\
582\end{array}$ & $\begin{array}{l}\mathrm{C}_{30} \mathrm{H}_{60} \mathrm{O}_{3} \\
\mathrm{C}_{32} \mathrm{H}_{64} \mathrm{O}_{3}\end{array}$ & $\begin{array}{l}\mathrm{C}_{14} \mathrm{H}_{29} \\
\mathrm{C}_{16} \mathrm{H}_{33}\end{array}$ & $\begin{array}{l}0 \\
0\end{array}$ \\
\hline & II & $\begin{array}{l}311 \\
313 \\
339\end{array}$ & $\begin{array}{l}341 \\
369 \\
397\end{array}$ & $\begin{array}{l}460 \\
488 \\
490 \\
516\end{array}$ & $\begin{array}{l}535 \\
563 \\
565 \\
591\end{array}$ & $\begin{array}{l}550 \\
578 \\
580 \\
606\end{array}$ & $\begin{array}{l}\mathrm{C}_{30} \mathrm{H}_{56} \mathrm{O}_{3} \\
\mathrm{C}_{32} \mathrm{H}_{60} \mathrm{O}_{3} \\
\mathrm{C}_{32} \mathrm{H}_{62} \mathrm{O}_{3} \\
\mathrm{C}_{34} \mathrm{H}_{64} \mathrm{O}_{3}\end{array}$ & $\begin{array}{l}\mathrm{C}_{14} \mathrm{H}_{27} \\
\mathrm{C}_{16} \mathrm{H}_{31} \\
\mathrm{C}_{18} \mathrm{H}_{35}\end{array}$ & $\begin{array}{l}2 \\
2 \\
1 \\
2\end{array}$ \\
\hline \multirow[t]{2}{*}{ C. striatum } & I & $\begin{array}{l}285 \\
313\end{array}$ & $\begin{array}{l}343 \\
371\end{array}$ & $\begin{array}{l}464 \\
492\end{array}$ & $\begin{array}{l}539 \\
567\end{array}$ & $\begin{array}{l}554 \\
582\end{array}$ & $\begin{array}{l}\mathrm{C}_{30} \mathrm{H}_{60} \mathrm{O}_{3} \\
\mathrm{C}_{32} \mathrm{H}_{64} \mathrm{O}_{3}\end{array}$ & $\begin{array}{l}\mathrm{C}_{14} \mathrm{H}_{29} \\
\mathrm{C}_{16} \mathrm{H}_{33}\end{array}$ & $\begin{array}{l}0 \\
0\end{array}$ \\
\hline & II & $\begin{array}{l}283 \\
285 \\
311 \\
339\end{array}$ & $\begin{array}{l}341 \\
369 \\
371 \\
397\end{array}$ & $\begin{array}{l}462 \\
464 \\
488 \\
490 \\
516 \\
544\end{array}$ & $\begin{array}{l}537 \\
539 \\
563 \\
565 \\
591 \\
619\end{array}$ & $\begin{array}{l}552 \\
554 \\
578 \\
580 \\
606 \\
634\end{array}$ & $\begin{array}{l}\mathrm{C}_{30} \mathrm{H}_{58} \mathrm{O}_{3} \\
\mathrm{C}_{30} \mathrm{H}_{60} \mathrm{O}_{3} \\
\mathrm{C}_{32} \mathrm{H}_{60} \mathrm{O}_{3} \\
\mathrm{C}_{32} \mathrm{H}_{62} \mathrm{O}_{3} \\
\mathrm{C}_{34} \mathrm{H}_{64} \mathrm{O}_{3} \\
\mathrm{C}_{36} \mathrm{H}_{68} \mathrm{O}_{3}\end{array}$ & $\begin{array}{l}\mathrm{C}_{14} \mathrm{H}_{27} \\
\mathrm{C}_{16} \mathrm{H}_{31} \\
\mathrm{C}_{16} \mathrm{H}_{33} \\
\mathrm{C}_{18} \mathrm{H}_{35}\end{array}$ & $\begin{array}{l}1 \\
0 \\
2 \\
1 \\
2 \\
2\end{array}$ \\
\hline
\end{tabular}

The formulae, the degree of unsaturation and the side-chain length of corynomycolates isolated from various strains are given in Table 2 . Thus the corynomycolic acids $\left(\mathrm{C}_{30}-\mathrm{C}_{34}\right)$ of the three strains consisted of saturated compounds with $C_{14: 0}, C_{16: 0}$ and $C_{18: 0}$ side chains when cells were grown without Tween 80 . In cells grown in the presence of Tween 80 , corynomycolic acids were composed of mono-unsaturated and, particularly, di-unsaturated compounds with $C_{14: 1}, C_{16: 1}$ and $C_{18: 1}$ side chains, the major components being $C_{32}, C_{34}$ and $C_{36}$ acids. 


\section{DISCUSSION}

The three strains of cutaneous corynebacteria examined contained saturated corynomycolic acids with 26 to 36 carbon atoms. However, when cells were grown in the presence of Tween 80 , the degree of unsaturation of the side chains was increased. There was also an increase in the amount of $\mathrm{C}_{36}$ mycolic acids and a corresponding decrease in the amount of $\mathrm{C}_{30}$ mycolic acids. These results are generally in agreement with those of Athalye et al. (1984) for JK corynebacteria and of McGinley et al. (1985 b) in respect of JK corynebacteria and lipophilic diphtheroids. It is also of note that the two JK group corynebacteria had much lower levels of corynomycolic acids when grown in the absence of Tween 80 .

Whatever the growth conditions, the three strains examined were markedly distinct from Corynebacterium bovis, whose $\mathrm{C}_{30}-\mathrm{C}_{36}$ content ranges from $12.0 \%$ (Athalye et al., 1984) to $27.5 \%$ (McGinley et al., 1985a,b) of total mycolic acid content and which has a low amount of $\mathrm{C}_{30}-\mathrm{C}_{32}$ (Collins et al., 1982). Our strains were quite similar in mycolic acid composition to Corynebacterium diphtheriae, Corynebacterium xerosis and Corynebacterium minutissimum (Collins et al., 1982; Athalye et al., 1984; McGinley et al., 1985a, b).

Changes in mycolic acids similar to those reported here have been associated with different growth temperatures in Nocardia asteroides (Tomiyasu, 1982), Nocardia rubra (Tomiyasu et al., 1981) and Mycobacterium phlei (Toriyama et al., 1980). Mycolic acid composition obviously depends on environmental conditions. In strains grown in the presence of Tween 80, mono- and di-unsaturated species constituted the major corynomycolic acids, and levels of mycolic acid with 36 carbon atoms and two double bonds increased significantly. PyGC and MS analyses suggest that one of the double bonds of di-unsaturated corynomycolic acids is located in the main chain and the other in the side chain (Ioneda et al., 1979; Thomas et al., 1979). High levels of $\mathrm{C}_{36: 2}$ corynomycolic acid occur in cells grown in the presence of Tween 80 and it may be that synthesis involves the condensation of two molecules of oleic acid $\left(\mathrm{C}_{18: 1}\right)$. Indeed previous results show that the $C_{18: 1}$ fatty acid content is increased in bacteria grown with Tween 80 (Athalye et al., 1985).

In conclusion, we have demonstrated that the presence of Tween 80 in the culture medium increased the level of corynomycolic acids and modified the composition in corynebacteria strains. This finding confirms the interest of the characterization of corynomycolic acids, either in presence or in absence of Tween 80 , in the classification of corynebacteria among cutaneous saprophytic or pathogenic bacteria.

\section{REFERENCES}

Athalye, M., Noble, W. C., Mallet, A. I. \& Minnikin, D. E. (1984). Gas chromatography-mass spectrometry of mycolic acids as a tool in the identification of medically important coryneform bacteria. Journal of General Microbiology 130, 513519.

Athalye, M., Noble, W. C. \& Minnikin, D. E. (1985). Analysis of cellular fatty acids by gas chromatography as a tool in the identification of medically important coryneform bacteria. Journal of Applied Bacteriology 58, 507-512.

Collins, M. D., Goodfellow, M. \& Minnikin, D. E. (1982). A survey of the structures of mycolic acids in Corynebacterium and related taxa. Journal of General Microbiology 128, 129-149.

CoOper, D. G., Zajic, J. E. \& Fergus Gracey, D. E. (1979). Analysis of corynomycolic acids and other fatty acids produced by Corynebacterium lepus grown on kerosene. Journal of Bacteriology 137, 795-801.

Corina, D. L. \& SESARdic, D. (1980). Profile analysis of total mycolic acids from skin corynebacteria and from named Corynebacterium strains by gas-liquid chromatography and gas-liquid chromatography/ mass spectrometry. Journal of General Microbiology 116, 61-68.

Etemadi, A. H. (1967). The use of pyrolysis gas chromatography and mass spectrometry in the study of the structure of mycolic acids. Journal of Gas Chromatography 5, 447-456.

Gailly, C., Sandra, P., Verzele, M. \& Cocito, C. (1982). Analysis of mycolic acids from a group of corynebacteria by capillary gas chromatography and mass spectrometry. European Journal of Biochemistry 125, 83-94.

Goodfellow, M., Collins, M. D. \& Minnikin, D. E. (1976). Thin-layer chromatographic analysis of mycolic acid and other long-chain components in whole-organism methanolysates of coryneform and related taxa. Journal of General Microbiology 96, 351358.

Ioneda, T., Silva, C. L. \& Thomas, D. W. (1979). Studies on the structure of $\alpha$-branched $\beta$-hydroxylated fatty acids from Corynebacterium ovis (C. pseudotuberculosis). Chemistry and Physics of Lipids 24, 1-9.

McGinley, K. J., Labows, J. N., Zechman, J. M., NordStrom, K. M., WebSTER, G. F. \& LEYdEN, J. J. 
(1985a). Analysis of cellular components, biochemical reactions and habitat of human cutaneous lipophilic diphtheroids. Journal of Investigative Dermatology 85, 374-377.

McGinley, K. J., Labows, J. N., Zechman, J. M., NoRdstrom, K. M., WebSter, G. F. \& LEYden, J. J. (1985b). Pathogenic JK group corynebacteria and their similarity to human cutaneous lipophilic diphtheroids. Journal of Infectious Diseases 152, 801-806.

Michalec, C., Mara, M. \& Adamcoua, D. (1975). Qualitative and quantitative thin-layer chromatography of mycolic acids in Mycobacterium tuberculosis var-bovis-BCG. Journal of Chromatography 104, 460-464.

MinNikin, D. E. \& Goodfellow, M. (1976). Lipid composition in the classification and identification of Nocardia and related taxa. In The Biology of the Nocardiae pp. 160-219. Edited by M. Goodfellow, G. H. Brownell \& J. A. Surans. London: Academic Press.

Minnikin, D. E., Alshamaony, L. \& Goodfellow, M. (1975). Differentiation of Mycobacterium, Nocardia and related taxa by thin-layer chromatographic analysis of whole-organism methanolysates. Journal of General Microbiology 88, 200-204.

Minnikin, D. E., Goodfellow, M. \& Collins, M. D. (1978). Lipid composition in the classification and identification of coryneform and related taxa. In Coryneform Bacteria, pp. 85-160. Edited by I. J. Bousfield \& A. G. Callely. London: Academic Press.

Minnikin, D. E., Hutchinson, I. G., Caldicott, A. B. \& Goodfellow, M. (1980). Thin layer chromatography of methanolysates of mycolic acid containing bacteria. Journal of Chromatography 188, 221-233.

POMMIER, M. T. \& MicheL, G. (1985). Occurrence of corynomycolic acids in strains of Nocardia otitidis- caviarum. Journal of General Microbiology 131, 26372641.

Riley, P. S., Hollis, D. G., Utter, G. B., Weaver, R. E. \& BAKER, C. N. (1979). Characterization of 95 diphtheroid (JK) cultures isolated from clinical specimens. Journal of Clinical Microbiology 9, 418427.

Suzuki, T., Tanaka, K., Matsubara, I. \& Kinoshita, S. (1969). Trehalose lipid and $\alpha$-branched $\beta$-hydroxy fatty acid formed by bacteria grown on $n$-alkanes. Agricultural and Biological Chemistry 33, 1619-1627.

Thomas, D. W., Matida, A. K., Sylva, C. L. \& IONEDA, T. (1979). Esters of trehalose from Corynebacterium diphtheriae: a modified purification procedure and studies on the structure of their constituent hydroxylated fatty acids. Chemistry and Physics of Lipids 23, 267-282.

TOMIYASU, I. (1982). Mycolic acid composition and thermally adaptative changes in Nocardia asteroides. Journal of Bacteriology 151, 828-837.

Tomiyasu, I., Toriyama, S., Yano, I. \& Masui, M. (1981). Changes in molecular species composition of nocardomycolic acids in Nocardia rubra by the growth temperature. Chemistry and Physics of Lipids 28, 41-54.

Toriyama, S., Yano, I., Masui, M., Kusunose, E., Kusunose, M. \& AKIMORI, N. (1980). Regulation of cell wall mycolic acid biosynthesis in acid-fast bacteria. I. Temperatures induced changes in mycolic acid molecular species and related compounds in Mycobacterium phlei. Journal of Biochemistry 88, 211221.

Yano, I., Kageyama, K., Ohno, Y., Masui, M., Kusunose, E., Kusunose, M. \& AKImori, N. (1978). Separation and analysis of molecular species of mycolic acids in Nocardia and related taxa by gas chromatography mass spectrometry. Biomedical Mass Spectrometry 5, 14-24. 